\title{
Relationship between Internal Marketing and Service Quality with Customers' Satisfaction
}

\author{
Dr. Abdelmoti Suleiman Aburoub \\ Al-Ahliyya Amman University, Jordan \\ E-mail: emad75@hotmail.com \\ Dr. Abdullah Mohammad Hersh \\ Al Balqa Applied University, Jordan \\ E-mail: abdullah.hersh@gmail.com \\ Dr. Kalil Aladwan \\ Al Balqa Applied University, Jordan \\ E-mail: aladwan99@hotmail.com
}

Received: November 25, $2010 \quad$ Accepted: January 19, $2011 \quad$ doi:10.5539/ijms.v3n2p107

\begin{abstract}
This study aims at investigating the relationship between internal marketing and service quality to customers' satisfaction in Jordan commercial banks, through answering the following questions: Do commercial banks in Jordan apply the appropriate concept of internal marketing? What are the possible procedures that can be applied in the banking sector? Is there any relationship between bank services quality and customer satisfaction?

In order to achieve the study objectives, two questionnaires were designed and distributed over two samples of Jordan bank employees and customers totaling (231) and (384) respectively. The questionnaires were collected and analyzed by using the SPSS. The study's conclusions are as follows:

-Study's sample attitudes were positive towards internal marketing (service culture, human resources development, motives system and rewards) totaling (0.5693) more than virtual mean

-Study's sample evaluations were positive towards internal marketing procedures from employees perspectives since its mean is more than the virtual mean (3), totaling (0.6935).

-Study's sample attitudes were positive towards banking service quality represented by (tangibility, reliability, responsiveness, assurance, empathy), since evaluations before benefiting from the banking service were (3.566) i.e. (0.566) more than the virtual mean, while after benefiting, the evaluations were $(0.778)$ more that the virtual mean.
\end{abstract}

Keywords: Internal marketing, Service quality, Customers' satisfaction, Commercial banks

\section{Introduction}

Generally, the Marketing of products and services has been focused on the detection and the satisfaction of the external customers needs. Many researches have been conducted, globally, with regard to the measurement of external customer's satisfaction (Codotte et al., 1987; Cronin and Taylor, 1992; Gerson, 1993; Kessler, 1996).

In services, customer's satisfaction or dissatisfaction takes place during the moments of truth - when customer comes in contact with a front-line employee of the firm (Lewis and Entwistle, 1990). Actually, at the moments of truth, the quality of provided services is the customer's judgment and the result from the discrepancy between customers' expectations and perceptions (Bitner, 1990; Bolton and Drew, 1991; Parasuraman et al., 1988; Taylor and Baker, 1994). So external customer satisfaction cannot be achieved without the fundamental contribution of the customer contact employees who provide the service. Thus, front-line employees should stay focused on customers' needs. One methods of creating this work environment which initiate and maintain the culture that 
may produce the appropriate behavior, is through Market Orientation (Hartline and Ferrell, 1996).

Moreover, because of the importance of the service provided, service firms should inform their customer-contact employees of the customer's needs, train them in a continual base, support them in order to acquire communication and recovery skills and make them feel comfortable and satisfied with their job. The above ascertainment emerged the concept of Internal Marketing. In that respect enterprises should develop marketing programmes focusing on the internal market (employees) in parallel to those for its external market (customers) (Bansal et al., 2001).

Relation between internal marketing of services depends on increasing stressing on good quality of banking service, since customers are no more only using banking service, but simply they prefer to participate in producing banking service that they make use of. This imposes on banks workers to understand customers' needs, wishes and preferences from the point of view of customers specifically.

Due to scarcity of local studies that deal with internal marketing, and good quality of service and their relation with customers' satisfaction, this study covers this gap from all sides whether from the point of view of banking establishments represented by workers, or the point of view of customers concerning their satisfaction about service quality provided to them by Jordanian Commercial Banks.

It is worth to mention that internal marketing is the practical application of the marketing philosophy and practices on individuals who serve customers, so that the mostly qualified individuals are employed and kept to perform their tasks in all respects.

As for service good quality, they are a group of characteristics that can satisfy customer's needs through providing services that conform with or excel the customer's expectations and specifications. Ethics of internal marketing show that customer's satisfaction is considered the expression of happiness and pleasure resulting from customer's comparison between performance of actual services that they get and their expectations.

\section{Literature Overview}

Berry (1981) pioneered the term internal marketing and originally defined it as "viewing employees as internal customers, viewing jobs as internal products that satisfy the needs and wants of these internal customers while addressing the objectives of the organization" (p.25). Since this time authors, practitioners, and researchers in this area have developed different definitions in order to explain their version of this idea (Ahmed, Rafiq and Saad, 2002; Ballantyne, 2003; Berry, 1981; Cahill, 1995; Lings and Brooks, 1998; Mudie, 2003; Prasad and Steffes, 2002; Rafiq and Ahmed, 2000; Varey and Lewis, 1999). The main ideas discussed evolved around the affects on employees (Ahmed et al., 2002; Ballantyne, 2003; Berry, 1981; Cahill, 1995; Lings and Brooks, 1998; Mudie, 2003; Prasad and Steffes, 2002; Rafiq and Ahmed, 2000; Varey and Lewis, 1999), the affects on the organizations (Ahmed et al., 2002; Ballantyne, Christopher and Payne, 1995; Lings, 1999; Mudie, 2003; Varey \& Lewis, 1999), external customer satisfaction (Ahmed and Rafiq, 2003; Cahill, 1995; Prasad and Steffes, 2002; Rafiq and Ahmed, 2000), and the development of cross functional units within the organization (Ahmed and Rafiq, 2003; Ballantyne, 2003; Rafiq and Ahmed, 2000). The affects on employees, organizations, external customer satisfaction, and the development of cross functional units assist in the creation of internal marketing.

In the service sector, quality is closely related to employee performance. An essential feature of any successful organisation is motivated employees. Therefore, the attitude of an employee towards his/her place of work and the extent to which an employer is able to motivate employees may have a direct effect on the quality of those products offered to tourists. One of the most important challenges facing managers is the creation of a context within which employees feel motivated and will act in order to achieve the goals of the organisation. Managers may, by influencing the context, affect the degree of motivation among the employees. Maybe nowhere, is the understanding of employee motivation more important than in a customer service oriented business such as the tourism industry (Lee-Ross, 1999a).

According to Bowen and Lawler (in Payne et al., 1999), there are four organizational ingredients that must be shared with employees:

“(1) information about the organization's performance, (2) rewards based on the organization's performance, (3) knowledge that enables employees to understand and contribute to organizational performance, and (4) power to make decisions that influence organizational direction and performance" (Payne et al, 1999, p. 139)

\subsection{The Origins of the Internal Marketing Concept}

The internal marketing concept emerged from service marketing and its main concern was "to get everyone who 
was involved in service encounters - the front line or contact staff - to perform better in the interaction with customer" (Gummesson, 2000, p. 27). The usage of the concept has extended beyond its traditional field and is now accepted in all kinds of organisations. In internal marketing, the internal market consists of the employees in the organisation and according to theories of quality management, employees are internal customers to one another. This is summarised by Gummesson (2000):

"An employee's ability to influence and satisfy the needs of others inside the organization is considered an antecedent to external customer satisfaction. Only if internal customer relationships work can the quality of the outcome be excellent, thus creating satisfied, or even better, delighted external customers" (Gummesson, 2000, p.28).

\subsection{Definitions of the Internal Marketing Concept}

Internal marketing term emerged out of the concept that says that employees form an internal market in the organization, this market needs training teaching and motivating workers to satisfy needs and expectations of external customers. Vary and Lewis (1998) pointed out that internal marketing was created in the seventies of the twentieth century as an administrative method to set up inculcate and provide good service. In the core of internal marketing lies the internal customers concept that emerged out of industry context and administration operations in the fifties on the twentieth century. (Al-Dmoor 2005) believes that internal marketing concept goes back to the end of seventies and start of eighties in the previous century.

Researchers and parishioners' interest in internal marketing increased because of increase in competition severity and growth the human needs. So, it became necessary to take care of internal marketing like interest in external marketing so as to achieve level of quality and performance required for service provided by establishments.

Internal customers concept emerged in the field of service marketing and then in service during previous decades, a mixture of concepts, theories, and work frames and profits, were derived under umbrella of the so-called internal marketing. Ethics pointed out that there is no unanimity for definition of internal marketing, which reflects ambiguity, besides no agreement about the conceptual work frame that explains and clarifies the internal marketing's administrative area, and even the correct usage of term. (Sargeant and Asif, 1998). Gilmore Says that there is confusion caused by content of internal marketing and applications is organizations. Restetal believes that internal marketing terms is used to refer to activities that the organization should carryout in order to attract and win hearts and minds of its employees to achieve distinguished service.

One of the most basic definitions of the concept internal marketing is, according to Cahill (1996), presented by Berry and Parasuraman in their book Marketing Services: Competing through Quality (1991):

"Internal marketing is attracting, developing, motivating, and retaining qualified employees through job-products that satisfy their needs. Internal marketing is the philosophy of treating employees as customersindeed, "wooing" employees...-and is the strategy of shaping job-products to fit human needs" (Cahill, 1996, p. $3)$.

This definition emphasises the importance of satisfying employees' needs in order to attract, develop, motivate and retain the best-qualified personnel and it has a strong influx of human resource management thinking. In fact, there has been some critique put forward concerning this matter, in which a line between human resource management and marketing has been attempted to be drawn (Rafiq and Ahmed, 1993; Ballantyne, 2000).

Some definitions of the concept emphasise customer-consciousness and sales-mindedness among the personnel, such as Johnson and Seymour (1985), which argue that internal marketing activities ought to:

"create an internal environment which supports customerconsciousness and sales-mindedness" (Johnson and Seymour, 1985, p. 226) and Grönroos' (1994) definition of the concept, which states that: "the internal market of employees is best motivated for service mindedness and customer-oriented performance by an active, marketing-like approach, where a variety of activities are used internally in an active, marketinglike and coordinated way" (Grönroos, 1994, p. 13).

Other definitions of internal marketing underscore the importance of an understanding of the firm's mission and objectives among the employees, such as Johnson, Scheuing, and Gaida (1986), who define it as a:

"service firm's efforts to provide all members of the organization with a clear understanding of the corporate mission and objectives and with the training, motivation, and evaluation to achieve the desired objectives" (Johnson, Scheuing and Gaida, 1986, p.140).

Recent definitions of the concept stress the purpose of enhancing service quality: "It is a strategy for developing relationships between staff across internal organisational boundaries. This is done so that staff autonomy and 
know-how may combine in opening up knowledge generating processes that challenge any internal activities that need to be changed. The purpose of this activity is to enhance quality of external marketing relationships (Ballantyne, 2000, p.43). In sum, these definitions indicate that internal marketing is a philosophy for the management of comparatively large service organisations, where the employees are viewed as a customer market and with the overall objective of enhancing the service quality

\subsection{Internal Marketing and Service Quality}

Interest in internal marketing increased as one reason that support great role of service organizations in achieving employees' and customers' satisfaction. (Kolter and Armstrong, 2006) has developed service marketing's triangle, which explains relation between organization and its employees and customers. In this triangle, they propose three forms of marketing each of which is considered a main factor in success of the organization.

First Type: External marketing that represents organization's relation with customers, and cares for traditional activities (product, price, distribution, and promotion).

Send Type: Interactive marketing that represents interactive relationship between service provider and customers. Interactive marketing means that determining service quality depends firstly and largely on interaction of quality standard from the point of view of service provider and beneficiary, (Gronross, 1994).

Third Type: Internal marketing that is interested in relationship between organization and its workers. It means that service organizations will train workers and motivate them especially these working in direct contact with customers.

Marketing forms in service industry were clarified through figure 1.

Reaching customers and winning their satisfaction is achieved through reaching level of quality required in all marketing relations between organization and customers.

First benefit that Banks achieve from applying internal marketing programs, is improvement of service goodness through bank individuals' focus on providing distinguished service to his/her colleagues which lead to find distinguished service that is received by customers (Al-Ofaishat, 2001).

Lan Lings (2000) explains that workers satisfaction is a basic condition and first step to achieve and customers satisfaction. Besides, service goodness is connected basically with quality of individuals who produce and provide these services. Therefore, reaching quality of services required and achieving customers satisfaction depends on using internal marketing program that satisfies needs and conforms to aspirations of working individuals. (Lings, 2000).

Customers' feeling of quality of service provided to them by individuals working in banks with whom they become in contract, is affected by level of those worker's performance. Success of external marketing basically depends on individuals with whom the customers intercommunicate, since qualified and well motivating individuals basically depends on individuals with whom the customers intercommunicate since qualified and well motivating individuals basically participate in creating and magnifying organization's outputs.

\subsection{Service Quality Concept}

Allerd (2001) points out that service quality means to conform with or adapt with requirements, this means that service establishments should create specific requirements and specifications for services it provides. Consequently, the goal of making various jobs of organization of quality is the whole conformity of such jobs with specifications and requirements defined by the organization. Generally it is known that customers take into consideration numerous dimensions when evaluating quality.

Besides there are many opinions concerning the explanation of service quality dimension. Various definitions of service quality have been mentioned. The researcher believes that some of them were mentioned in this study. (Parasaraman, Zeithmal and Berry, 1988) defines service quality as the difference between customers' expectations of provided service performance and their evaluation of actual service.

Asubonteng defines it as the difference between customers expectations of guided service performance and their realization of actual service. (Da'boul and Ayyoub, 2003) refer to service quality as the conformity with specifications.

In other words, organization should put forward standards for specifications when they put quality goals. After defining these goals, service should conform to these specifications. (Zeithaml and Bitner, 2006) see service quality as the concentrated evaluation that reflects the customer realization of specified dimension for service, such as: Reliability, responsiveness, confirmation, good dealing and material evidence. 
When customers' realization is mentioned, it is done on assumption of various quality dimensions and methods used by customers in evaluating such quality, whether they were internal customers (workers) or external customers (individuals, organizations).

Dehghan (2006) pointed out to the service quality as the objective comparison carried out by customers between service quality that they wish to obtain and actual service that they get. (Lovelock and wirtz, 2004) define it as having various concepts and meanings according to customers difference, and way through which they realize quality of service provided to them.

Four Points of View In Defining Quality Are As Follows:

Point of view concerning with user himself: It means that the quality lies in the customer's opinion. Consequently, those customers have their own wishes and needs, it is noticeable that this definition equalize between quality and achieving farthest satisfaction of customers.

Point of view based on product: It considers quality as a sensitive variable that can be measured; difference in quality reflects amount of difference in variable contents or characteristics of the product.

Intellectual point of view: means conformity of quality with standards and effective performance, in it, individual realize quality through experience of them that they acquired by repeated exposure.

Point of view concerning value: It considers quality from price and value, through comparison between performance obtained by customer and price he/she pays for the service obtained.

\subsection{Service Quality Dimensions}

Researchers do not agreed upon essence of services quality dimensions because it is difficult for service organizations to put forward observation procedures to define standards of service quality provided to customers. Nevertheless, (Parasuraman, Zeithaml and Berry, 1985) refer to the existence of service quality ten dimensions which are:

Credibility: means possibility of service provider obligations and if he/she is worthy of trust.

Responsiveness: readiness of service, provider to achieve and perform service accurately and in a reliable way.

Reliability: it refers to service supplier ability to achieve and perform service accurately and in a reliable way.

Security: it relates to degree of security and risk free.

Understanding: understanding customers and knowing their needs accurately.

Tangibles: It refers to aspect of material facilities provided to the service organization, such as, supplies, tools, individuals... etc.

Accessibility: means that service is available in place and time wished by the customer.

Courtesy: means service provider's high degree of respect and consideration of customer feelings and dealing with them with cordiality.

Competence: service provider's haring skills and knowledge required.

Communication: if service provider is able to enlighten beneficiary about nature of service provided, and the role that beneficiary should play to obtain service required, for example, is beneficiary informed with damages or obstacles that may occur in service providing systems? (Al- Tai'e and Al-Alaq, 2009).

Service quality dimensions were decreased to become five; they are reliability, tangibles, responsiveness, credibility, and empathy.

\subsection{Customers Satisfaction Concept}

Customers satisfaction in the first place in interested in defining of buying behavior. The research stressed the customer's satisfaction role in focusing on expectation, performance achieved, and satisfaction. Comparison between expectation and performance achieved leads either to customers satisfaction or dissatisfaction of customer.

Customers satisfaction was defined in $\mathrm{m}$ any different manners. At present, researchers argue that there is a difference between customers satisfaction concerning tangible products and customers satisfaction concerning services.

Since customers satisfaction about services and product may be affected by various factors, it should be dealt with as a separate subject (Zoe, 2006). 


\section{Study Hypotheses}

The study is based on a group of general hypotheses and Sub hypotheses to study nature of relationship between internal marketing and service quality with customers' satisfaction. Here is a summary of these hypotheses which are taken from the study form (Figure 2.).

H1: There is a relation of statistical indication between internal marketing procedures and evaluation of internal marketing procedures. From this hypothesis, the following branch hypotheses emerge.

H1a: There is a relation of statistical indication between service culture and evaluation of internal marketing procedures.

H1b: There is a relation of statistical indication between human resources development and evaluation of internal marketing procedures.

H1c: There is a relation of statistical indication between data publication and evaluation of internal marketing procedures.

H1d: There is a relation of statistical indication between motives and rewards, and evaluation of internal marketing procedures.

$\mathrm{H} 2$ : There is a relation of statistical indication between banking service quality and customers satisfaction in the Jordanian Commercial Banks, from this hypothesis, the following branch hypotheses emerge:

H2a: There is a relation of statistical indication between reliability, and customers satisfaction in the Jordanian Commercial Banks.

$\mathrm{H} 2 \mathrm{~b}$ : There is a relation of statistical indication between responsiveness, and customers satisfaction in the Jordanian Commercial Banks.

$\mathrm{H} 2 \mathrm{c}$ : There is a relation of statistical indication between tangibles and customers satisfaction in the Jordanian Commercial Banks.

$\mathrm{H} 2 \mathrm{~d}$ : There is a relation of statistical indication between empathy, and customers satisfaction in the Jordanian Commercial Banks.

H2e: There is a relation of statistical indication between credibility, and customers satisfaction in the Jordanian Commercial Banks.

H3: There is a relation of statistical indication between evaluations of internal marketing procedures and quality of banking service that affect customers satisfaction.

\section{Goals of the Study}

The present study aims to know internal marketing and banking quality and their relation with customer's satisfaction, and the ability of Jordanian Commercial Banks to adopt the mechanism of internal marketing as a philosophy to deal with workers, and making it their competitive characteristic in comparison with the other banks.

This Study Also Aims To Achieve The Following:

To show degree of Jordanian Commercial Banks' application of internal marketing procedures.

Analysis of relation between internal marketing and banking service's quality and the satisfaction of customers in banks working in Jordan.

To show degree of worker's in banks working in Jordan evaluation of internal marketing procedures.

To determine degree of customers evaluation of banking service quality.

To present recommendations and proposals that participate in achieving suitable improvements in the nature of services presented to customers.

\section{Society and Sample of Study}

This study is distinguished because it addresses two societies concerned with banking sector, first the workers of banks and second those bank's customers. Due to difficulty of reaching both societies a sample representing each society by itself will be chosen (300) from banks workers and (500) banks customers.

\section{Finding}

\subsection{Results Relating to Employees}

Tendencies of study sample (banks employees) towards internal marketing procedures, represented by: Service 
culture, human resources development, marketing data publishing, motives and rewards system, were positive, about $(0.5693)$ of the general arithmetic means, resulting in the next equation (3.5693-3.0000). This conforms with Haddad and Ali's (2008) study.

It is clear from statistical analysis results that the administration of Commercial Banks working in Jordan, the research sample, gives a great attention to develop human resources, because it obtained the highest evaluation from the point of view of employees of (0.8978) higher than measure means average (3). Marketing data publication was in the second place, of (0.7950) the third place was occupied by rewards and motives system applied in banking administrations, it obtained (0.7700) higher than measure means average (3). The last place was occupied by banking service culture and obtained only ( 0.2143$)$, higher than measure means average (3). From this, the researcher concluded that there is negligence in publication the banking service culture among employees, in spite of obtaining an average higher than general average.

As for internal marketing procedures evaluation from the point of employees, it was positive, because it obtained an average higher than measure means average (3) with $(3.6935-3.000)=0.6935$, it is a good indicator because employees feel that the internal marketing procedures applied in Commercial Banks working in Jordan are fair, but they need more support because they feel that the important, substantial paragraph has obtained the least evaluation, in the last place, which is: (the bank always satisfies the customer's expectations). The strange thing in the point of view of the researcher is that the paragraph that obtained number one, that is the highest positive evaluation from the point of view of employees is: the bank never disappoints the customer.

- Jordanian banks' administration, the research sample, observes providing banking services of high quality.

- There is obvious negligence in availing new and developed programs to serve customers of Commercial Banks working in Jordan.

- Commercial Banks working in Jordan (Study sample) seek to attract, draw and employee technical cadres specialized in banking services.

- Employees in Commercial Banks working in Jordan (Study sample) see that they need concentrated and intensive training courses in order to increase skills, knowledge and expertise.

- Commercial Banks working in Jordan publish marketing data, especially those relating to new services to employees.

- There is negligence in using technology and programming to develop capacity of banks employees.

- There is a fair system of motives and rewards in Commercial Banks working in Jordan, according to point of view of Commercial Banks employees working in Jordan (study sample).

- Monthly salary does not conform to working hours and efforts made by employees, according to point of view of workers in Commercial Banks working in Jordan (Study sample).

- There is a relation of statistical indication between internal marketing procedures and evaluation of internal marketing procedures.

- There is a relation of statistical indication between banking service culture, human resources development, marketing data publication, motives and rewards system, and evaluation of internal marketing procedures.

\subsection{Results Relation to Customers}

On the basis of statistical analysis of study results, the following results concerning customers were concluded:

Tendencies of Commercial Banks' customers, working in Jordan were positive towards banking service quality dimensions represented in: tangibles, readability, responsiveness, credibility, empathy, where evaluations were before making use of banking service, of (3.566) that is an increase that reached to (0.566) more than average. But after making use of banking service, it increased and reached (0.778). This means that difference between customers' circumstances before making use of and after making use of banking services reached (0.212). This is an indicator that is somehow accepted.

Statistical analysis results point out that tangibles dimension won positive evaluation from the point in Jordan where it obtained a difference higher than average of (0.254), the best item that obtained first place that states the Commercial Banks, working in Jordan, having distinguished modern supplies and tools. This conclusion confirms degree of customers' interest in tangibles of banks, which in turn, participate in fast providing of banking services in suitable time and place.

Statistical analysis results confirm that the reliability dimension obtained the least evaluation from the customers' point of view in comparison with other quality dimensions by $(0.147)$ which is very little percentage. Although 
all items forming this dimension have obtained positive evaluation. The best item that obtained the highest percentage which states that employees in Commercial Banks working in Jordan perform their services entrusted to them will from the first time. But also, they can't be relief on, in solving problems facing bank's customers as soon as possible and on time required.

Statistical analysis results show that the responsiveness dimension obtained a positive evaluation from the customers' point of view, and by a difference that reached to (0.206) before and after making use of banking service, the important thing for customers is that they found workers in Commercial Banks working in Jordan seek to satisfy personal needs and demands. This means that banks employees (study sample) respond to their customers demands and are able to satisfy them. This conforms with Al-Tamimi study (2005).

Based on statistical analysis results, we conclude that credibility dimension has obtained positive evaluations for all its items from the customers' point of view, where it reached a difference of $(0.226)$. Here, we should point out that the item that obtained more than one in evaluation compared with average after making use to (4.190) which states that bankers' employees have enough knowledge of nature of service that they provide to customers.

Employees in Commercial Banks working in Jordan have empathy with customers through considering customers' interests by the banks' employees at the top of their priorities. This means that empathy dimension has obtained positive evaluation by $(0.224)$ from the customers' point of view.

It is obvious from statistical analysis results that level of satisfaction by customers of Commercial Banks working in Jordan has positive, since it reached (4.207) after making use of banking service, that is by a positive difference of (0.207), this percentage is more that the average which is (3). The item whose evaluation was positive and more than (one) measuring by average before making use of banking service that is the bank does not disappoint me during period of dealing with it. This is a positive indicator for nature of relationship between banks and their customers.

- There is a relation of statistical indication between banking service quality and customers' satisfaction, this identical with Abu Musa study (2000).

- There is a relation of statistical indication between banking service quality and (service quality dimensions): Tangibles, reliability, responsiveness, credibility, and customers' satisfaction. This study conforms to results of Zaarour's (2003)study and the Michael et al's (2009) study.

- There is a relation of statistical indication between evaluation of internal marketing procedures and customers' satisfaction.

\section{Limitations}

- This study included only Commercial Banks working in Jordanian in the Capital, Amman.

- This study was performed on workers in Commercial Banks working in Jordan, Amman, the capital, and bank's customers of them during the period of the study only.

- limitation from a conceptual standpoint is that regardless of the study outcomes, organizational management theorists still may believe that internal marketing is a human resource phenomenon with a marketing twist (Mudie, 2003).

\section{Implications}

The idea of creation and cultivation of internal marketing allows for a change in the Banks where new set of goals and institutional objectives may be created (Wasmer and Bruner II, 1991). While backlash may result for employees and the importance of timing to implement these changes is a major issue, this concept allows for the improvement of communication, departmental interaction, and if accomplished provide profitability for the Bank and fulfill the needs of employees.

The integration of the ideas discussed must be accomplished in order to obtain success. The internal marketing plan must be implemented by top management, human resources, and marketing and supported by all areas. Crosby and Johnson (2003) described the importance of leadership and the need for these individuals to "walk the talk", understand the reality of the workplace through hands on assistance, and understand the affects on profitability for a successful internal marketing campaign.

All employees must be treated as customers, this means the creation of specifications, the creation of awareness, and the identification of expectations through market research. The results of this research will allow the banks and other organizations to segment the population and tailor specific strategies to each segment; the procedures 
implemented may be examined through staff climate monitors (Ahmed et al., 2002). Once the segments are identified the communication of information is important and this includes additional training for all employees to develop competence, the creation of interdepartmental teams in order to build relationships, and the allowance for appraisal and feedback from within various levels of the organization. The unification of departments will allow suppliers to make necessary changes, establish a level of service quality, support quality improvement, and establish a level of customer consciousness.

Follow-up research must be conducted in order to determine effectiveness and assist in the recognition in changes of the environment (Hogg et al., 1998).

In order for proper implementation to occur the focus must evolve around frontline employees and the process must start with senior leadership and a proper physical environment. The best method to influence employees involves strategic awards, other incentives, and individual empowerment to make decisions without the assistance of upper management (Ahmed et al., 2002). Ballantyne (2003) stated a successful internal marketing campaign satisfies the interests of the individual member and organization.

Therefore, mutual value must exist, it must be transparent, perceived as fair, co-created through interaction, and continually increasing. The difference between this and external marketing is the fact it is continually co-created over time. If these ideas are properly.

\section{References}

Abu, M., \& Ahmad, A. (2000). Effect of the service quality on profitability and customer satisfaction in the Jordanian Commercial Banks: A Comparative Study between the Housing Bank and the Islamic Bank, unpublished Master Thesis, Al-Bayt University, Jordan .

Ahmed, P., \& Rafiq, M. (2003). Internal marketing issues and challenges. European Journal of Marketing, 37(9), $1177-1186$.

Ahmed, P., Rafiq, M., \& Saad, N. (2002). Internal Marketing and the mediating role of organisational competencies. European Journal of Marketing, 37(9), 1221-1241.

Al ofishat, \& Tayseer, M. (2001). Quality and customer satisfaction and its impact in determining marketing strategies for service banking: an analytical study of the views of a sample of Jordanian Commercial Banks. Unpublished Ph.D. thesis, University of Mosul, Iraq.

Allerd, A. T. (2001). Employees evaluations of service quality at banks and credit unions, The International Journal of Banking, 19(4), 179-185.

Ballantyne, D. (2000). The strengths and weaknesses of internal marketing, in Varey, R. J. and Lewis, B.R., Internal Marketing: Directions for Management, NY, Routledge, pp. 43 - 60.

Ballantyne, D. (2003). A relationship-mediated theory of internal marketing. European Journal of Marketing, 37(9), 1242-1260.

Ballantyne, D., Christopher, M., \& Payne, A. (1995). Improving the quality of services marketing: Service (Re)design is the critical link. Journal of Marketing Management, 11, 7-24.

Bansal, H. S., Mendelson, M. B., \& Sharma, B. (2001). The impact of internal marketing activities on external marketing outcomes. Journal of Quality Management, 6(1), 61-76.

Berry, L. (1981). The employee as customer. Journal of Retail Banking, 3, 25-28.

Berry, L. L., \& Parasuraman, A. (1991). Marketing Services Competing through Quality. The Free Press, Oxford.

Bitner, M. J. (1990). Evaluating service encounters: the effects of physical surroundings and employee responses. Journal of Marketing, 54, 69-82.

Bolton, R. N., \& Drew, J. H. (1991). A Longitudinal analysis of the impact of service changes on customer attitudes. Journal of Marketing, 55 (1), 1-9.

Bonn, M. A., \& Forbringer, L. R. (1992). Reducing turnover in the hospitality industry: an overview of recruitment, selection and retention. International Journal of Hospitality Management, 11(1), 47-63.

Cahill, D. (1995). The managerial implications of the learning organization: A new tool for internal marketing. Journal of Services Marketing, 9(4), 43-51.

Cahill, D. J. (1996). Internal Marketing: Your Company's Next Stage of Growth. New York: The Haworth Press, Inc. 
Codotte, E. R., Woodruff, R. W., \& Jenkins, R. L. (1987). Expectations and norms in models of consumer satisfaction. Journal of Marketing Research, 24, 305-314.

Cronin, J. J. Jr, \& Taylor, S. A. (1992). Measurement service quality a re-examination and extension. Journal of Marketing, 7, 55-68.

Crosby, L., \& Johnson, S. (2003). Watch what I do: Leadership behavior sends the strongest message. Marketing Management, Nov/Dec, 10-11.

Da'boal, Ayub, M. Z., \& Mohamed, (2003). Principles of Services Marketing, Damascus. Dar consent for publication.

Dehghan, A. (2006). Relationship between Service Quality and Customer Satisfaction. Luella University of Technology, Master Thesis.

Dmoor, H., \& Nusseirat, M. (2005). The effect of the marketing mix to attract Arab patients for treatment in Jordanian hospitals. Studies Journal, 31(2), 420-406.

Gerson, R. F. (1993). Measurement customer satisfaction. Crisp Publication Inc. Menlo Park, California

Grönroos, C. (1994). From Marketing Mix to Relationship Marketing: Towards a Paradigm Shift in Marketing. Management Decision, 32(2), 4-20.

Gronross, C. (1994). The service Quality Model and its Marketing Implications. European Journal of Marketing, $18,36-44$.

Gummesson, E. (2000). Internal marketing in the light of relationship marketing and network organizations, in Varey, R. J. and Lewis, B.R., Internal Marketing: Directions for Management, NY, Routledge, pp. 27-42.

Hartline, M. D., \& Ferrell, O. C. (1996). The management of customer-contact service employees: an empirical investigation. Journal of Marketing, 60(4), 52-70.

Hogg, G., Carter, S., \& Dunne, A. (1998). Investing in people: Internal marketing and corporate culture. Journal of Marketing Management, 14, 879-895.

Johnson, E. M., \& Seymour, D. T. (1985). The Impact of Cross Selling on the Service Encounter in Retail Banking In Czepiel, J.A., Solomon, M.R. and Surprenant, C. (eds.), The Service Encounter: Managing Employee/Customer Interaction in Service Business, Lexington, MA: Lexington Books, pp. 225-239.

Johnson, E. M., Scheuing, E. E., \& Gaida, K. A. (1986). Profitable Services Marketing. Homewood, IL: Dow-Jones Irwin.

Kessler, S. (1996). Measuring and managing customer satisfaction: Going for the gold. Milwaukee: ASQC Quality Press.

Kotler, P., \& Keller, K. L. (2006). Marketing Management. (12 ed). Upper Saddle River: Prentice Hall.

Lee-Ross, D. (1999a). HRM in Tourism \& Hospitality - International Perspectives in Small to Medium-sized Enterprizes. London: Cassell.

Lewis, B. A., \& Entwistle, T. W. (1990). Managing the service encounter: a focus on the employee. International Journal of Service Industry Management, 1 (3), 41-52.

Lings, I, N. (2000). Internal marketing and supply chain management. Journal of service marketing, 14 (1), 9.

Lings, I., \& Brooks, R. (1998). Implementing and measuring the effectiveness of internal marketing. Journal of Marketing Management, 14, 325-351.

Lings, L. (1999). Balancing internal and external market orientations. Journal of Marketing Management, 15, 239-263.

Lings, N. L., \& Greenly, E. G. (2005). Measuring Internal Market Orientation. Journal of Service Research, 7(3), 290-305.

Lovelock, C., \& Wirtz, J. (2004). Service Marketing People, Technology, Strategy. United States of America: Hamilton Printing Co, pp.106-107.

Michael, R., Nicholas, J. A., Shao, J., \& Carruethors, J. (2009). An Examination of the relationship between service Quality Dimensions, Overall Internet Banking Service Quality and a Customer satisfaction. A New Zealand Study. Marketing Intelligence and Planning, 27(1), 103-126.

Mudie, P. (2003). Internal customer: By design or by default. European Journal of Marketing, 37(9), 1261-1276. 
Parasuraman, A., Zeithaml, V., \& Berry, L. (1988). SERVQUAL-a multiple-item scale for measuring customer perceptions of service quality. Journal of Retailing, 64 (1), 12-40.

Prasad, A., \& Steffes, E. (2002). Internal marketing at Continental Airlines: Convincing employees that management knows best. Marketing Letters, 13(2), 75-89.

Rafiq, M., \& Ahmed, P. K. (2000). Advances in the internal marketing concept: Definition, synthesis, and extension. Journal of Services Marketing, 14(6), 449-462.

Sergeant, A., \& Asif, Saadia. (1998). The Strategic Application of Internal Marketing. International Journal of Bank Marketing, 16(7), 66-79.

Tai'e, H., \& Alalaq, B. (2009). Services Marketing, entrance of a strategic, functional, practical, Amman, Jordan: Yazouri House for Publishing and Distribution.

Taylor, S. A., \& Baker, T. L. (1994). An assessment of the relationship between service quality and customer satisfaction in the formation of customers' purchase intentions. Journal of Retailing, 70, 163-178.

Varey, J. R., \& Lewis, R. B. C. (1997). A Broadened Conception of Internal Marketing. European Journal of Marketing, 33(9-10), 926-944.

Wasmer, D., \& Bruner II, G. (1991). Using organizational culture to design internal marketing strategies. The Journal of Services Marketing, 5(1), 35-46.

Zeithaml, V. A., Bitner, M. J., \& Gremler, D. D. (2006). Service Marketing Integrating Customer Focus Across the Firm. New York: McGraw-Hill Erwin.

Zoe, S. D. (2006). Customer satisfaction, loyalty and commitment in Service organizations. Management Research News, 39(12), 98.

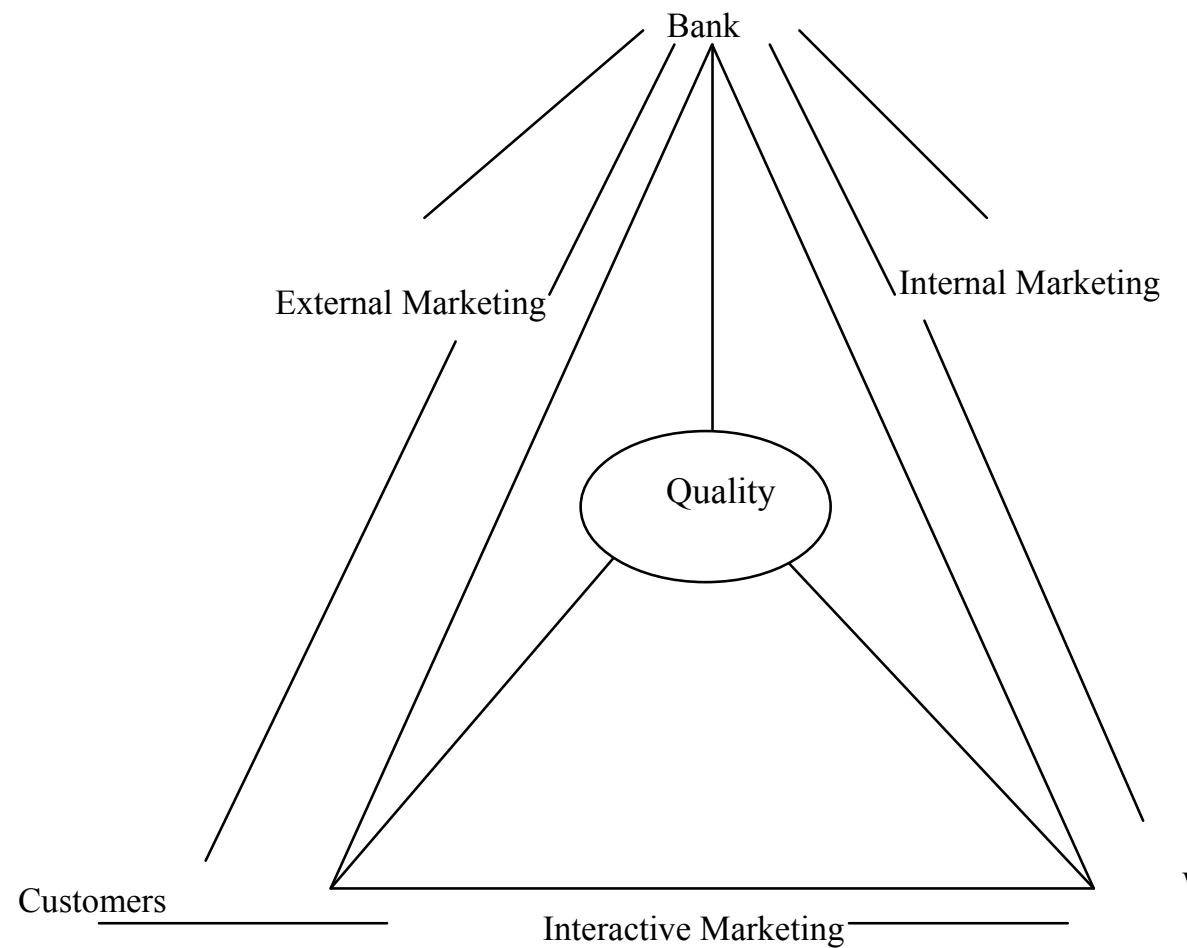

Workers

Figure 1. Marketing Forms in Services Industry

Kotler \& Armstrong (2006) 


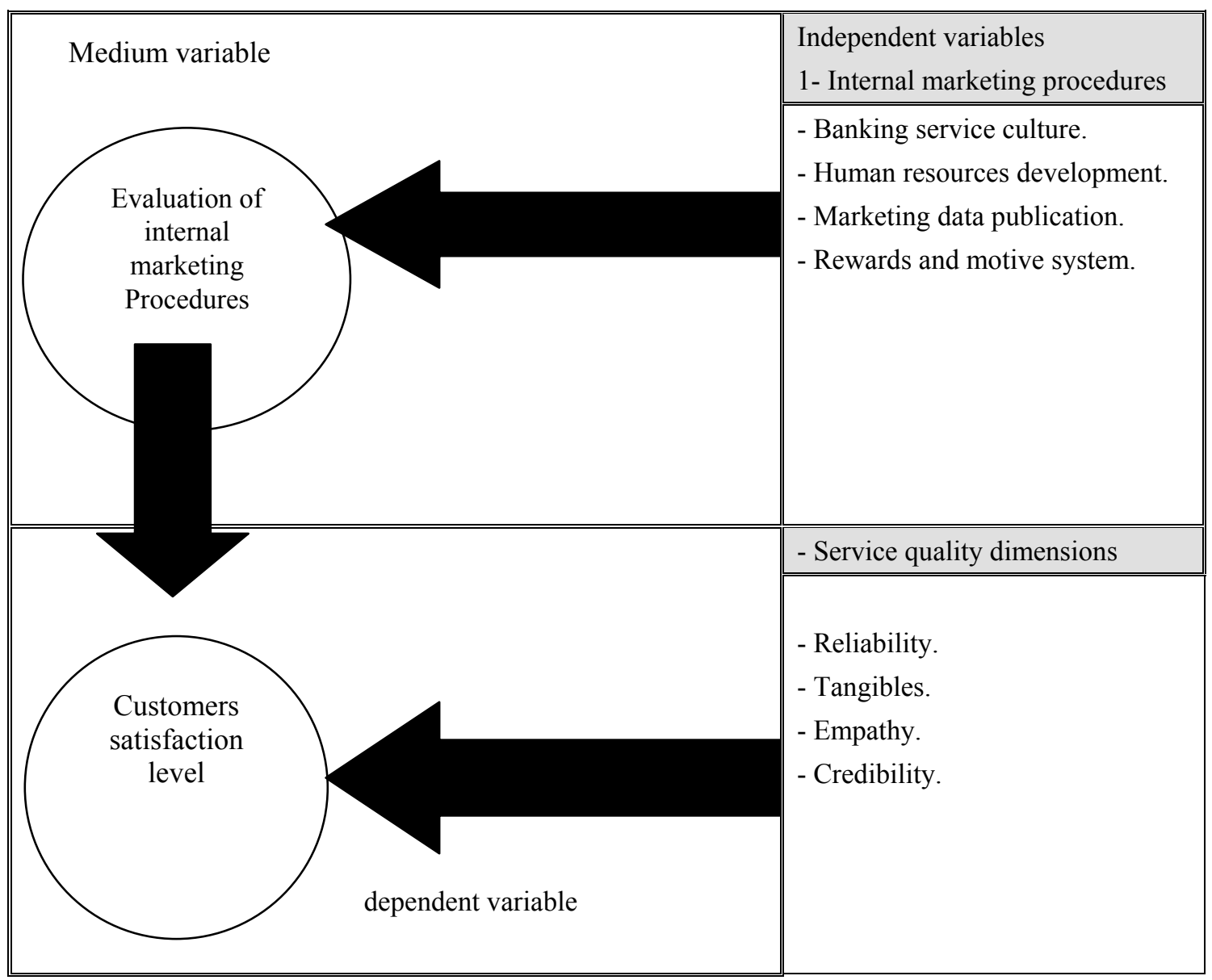

Figure 2. Study Model 